\title{
Article \\ Ecological Effects of Benzyl Chloride on Different Korean Aquatic Indigenous Species Using an Artificial Stream Mesocosm Simulating a Chemical Spill
}

\author{
Soo-Yeon Kim ${ }^{1,2}$, Seong-Hwan Park ${ }^{1}$, Dae-Wook Kim ${ }^{1}$, Won Noh ${ }^{1}$, Sang-Jun Lee ${ }^{1}$, Hee-Jin Jeong ${ }^{1}$, \\ Jong-Bin Park ${ }^{1}$, Yeong-Ji Gwak ${ }^{1}$, Jin-Woo Park ${ }^{1}$ and Dong-Hyuk Yeom ${ }^{1, *}$ \\ 1 Gyeongnam Branch Institute, Korea Institute of Toxicology (KIT), Jinju-si 52834, Korea; \\ sykim@kitox.re.kr (S.-Y.K.); seonghwan.park@kitox.re.kr (S.-H.P.); dwkim@kitox.re.kr (D.-W.K.); \\ won.noh@kitox.re.kr (W.N.); sjlee2013@kitox.re.kr (S.-J.L.); heejin.jeong@kitox.re.kr (H.-J.J.); \\ jongbin.park@kitox.re.kr (J.-B.P.); yeongji.gwak@kitox.re.kr (Y.-J.G.); parkjw@kitox.re.kr (J.-W.P.) \\ 2 Department of Energy Environmental System Engineering, Graduate School, University of Seoul, \\ Seoul 02504, Korea \\ * Correspondence: dhyeom@kitox.re.kr; Tel.: +82-55-750-3710
}

Citation: Kim, S.-Y.; Park, S.-H.; Kim D.-W.; Noh, W.; Lee, S.-J.; Jeong, H.-J.; Park, J.-B.; Gwak, Y.-J.; Park, J.-W.; Yeom, D.-H. Ecological Effects of Benzyl Chloride on Different Korean Aquatic Indigenous Species Using an Artificial Stream Mesocosm Simulating a Chemical Spill. Toxics 2021, 9, 347. https://doi.org/ $10.3390 /$ toxics 9120347

Academic Editors: Junho Jeon and Tae-Yong Jeong

Received: 6 October 2021

Accepted: 6 December 2021

Published: 9 December 2021

Publisher's Note: MDPI stays neutral with regard to jurisdictional claims in published maps and institutional affiliations.

Copyright: (c) 2021 by the authors. Licensee MDPI, Basel, Switzerland. This article is an open access article distributed under the terms and conditions of the Creative Commons Attribution (CC BY) license (https:/ / creativecommons.org/licenses/by/ $4.0 /)$.

\begin{abstract}
In this study, an artificial stream mesocosm consisting of a head tank, faster-flowing riffle section, gravel section, pool section, lower-run section, and tail tank was installed to simulate a chemical spill in a river. The responses of freshwater periphyton algae, crustacea (Moina macrocopa), freshwater worm (Limnodrilus hoffmeisteri), benthic midge (Glyptotendipes tokunagai), and fish (Zacco platypus and Aphyocypris chinensis) were observed after exposure to benzyl chloride (classified as an accident preparedness substance, APS) at concentrations of 1, 2, and $4 \mu \mathrm{L} / \mathrm{L}$ for $22.5 \mathrm{~h}$. Higher concentrations increased the inhibition (photosynthetic efficiency decrease) of periphyton algae and the mortality of M. macrocopa, whereas the reproduction of the female cladoceran decreased in the $4 \mu \mathrm{L} / \mathrm{L}$ treatment. Mortality of fish did not occur or was lower $(\leq 20 \%)$ at all concentrations; however, toxic symptoms were observed for some time after chemical exposure termination and later, symptoms receded. G. tokunagai mortality increased at all concentrations except the control after seven days, and no significant toxic effects were observed in L. hoffmeisteri. The hazardous concentration of benzyl chloride was calculated as $94 \mu \mathrm{g} / \mathrm{L}$. This study showed the different sensitivities of each species to benzyl chloride. The findings can assist in environmental risk assessment of APSs after chemical spills to protect Korean aquatic species.
\end{abstract}

Keywords: Korean indigenous species; risk assessment; benzyl chloride; artificial stream

\section{Introduction}

Benzyl chloride is used in various industrial purpose such as a chemical intermediate in the manufacture of certain dyes and pharmaceutical products, perfume, flavor products and as a photographic developer. It can be used in the manufacture of synthetic tannins and as a gum inhibitor in petrol [1] and the world consumption of benzyl chloride has increased steadily due to those diverse applications [2]. Industrial chemicals have the potential to cause chemical accidents, and the frequency of chemical accidents has increased with the increasing use of such chemicals [3]. According to the FACTS (Failure and Accidents Technical Information System) website, more than 25,700 industrial accidents occurred globally in the past 90 years, and there were five accidents involving benzyl chloride [4]. Recently, industrial chemical spills have continued to occur in Korea [5], and a total of 661 cases have occurred since 2014 [6]. A large chemical accident of hydrogen fluoride leak occurred in 2012, which has raised concerns regarding chemical safety, reemphasizing hazardous chemical management [7]. Consequently, the Toxic Chemical Control Act (TCCA) of Korea was revised in 2015, and 97 substances were classified as accident preparedness substances (APSs). APSs are highly likely to be involved in chemical 
accidents because of their strong acute toxicity or explosiveness, and they were included in the Korean TCCA to protect aquatic ecosystems from chemical accidents [8].

Benzyl chloride is one of the concerning APSs by Korean authorities and there are several potential ways in which it could be involved in a chemical accident. Hong et al. proposed a chronic health risk assessment method for multi-media exposure of benzyl chloride by chemical accident scenario [9]. Depending on the circumstances of an accident, benzyl chloride can be released into aquatic ecosystems, and hence, it is necessary to assess the toxicological effects on aquatic organisms. Generally, a chemical spill releases large amounts of chemical into river over a short period, which may cause potential adverse effects, such as delayed (chronic) toxicity, as well as immediate (acute) toxicity to aquatic organisms. Therefore, evaluating the ecological risks arising from these chemical accidents is necessary [10].

Laboratory toxicity tests are fundamental and common tools to evaluate ecotoxicological effects due to contaminants; however, they are insufficient to reflect the real river conditions. Thus, interpreting the results of monitoring studies, particularly in rivers, is often complicated. Artificial stream mesocosms provide an opportunity to advance understandings of ecological phenomena that occur in rivers as the environmental conditions can be more realistic than those in laboratory toxicity tests, but more controlled than in field studies [11]. Thus, mesocosm studies have been suggested for ecological risk assessments [12,13], and the fate and effect of hazardous chemicals in rivers can be evaluated using artificial stream mesocosms without causing any chemical damage to the real aquatic environment [14]. Such studies can assess the environmental impacts of potential stressors, and link laboratory and field conditions. Since the 1990s, various stream and pond mesocosm studies have been applied for assessing the risks posed by pesticides [15-20]. Besides pesticide studies, most mesocosm research related to chemical spills has focused on oil spills in marine ecosystems [21-23]. Moreover, recently, an increased number of mesocosm studies have been conducted to evaluate the impacts of microplastics on aquatic organisms $[24,25]$.

Exposure to chemicals during a chemical spill in a river occurs instantaneously and the concentration of the chemicals, subsequently, decreases, primarily by dilution. However, replicating this scenario for research is difficult and thus, modeling approaches have been developed [26]. Acute toxicity data derived from standard laboratory exposure conditions with a short duration could provide valuable information that can be used for risk assessment; however, these conditions do not represent direct chemical spills occurring in the environment. Chapman et al. [27] reported that applying safety factors to acute toxicity data with continuous exposure does not provide toxicity values for short-term exposures (for several hours) and may overestimate the risks. Bejarano and Farr [28] developed an estimation program to overcome this problem; however, this program is based on existing toxicity data using international standard species, and autochthonous species data were not included. Additionally, the lack of toxicity data for some chemicals has limited the accuracy of evaluations during chemical spills.

Accordingly, in the present study, an artificial stream mesocosm system that included six Korean indigenous aquatic species (the fish: Zacco platypus and Aphyocypris chinensis; the crustacea: Moina macrocopa; periphytic alga; the freshwater worm: Limnodrilus hoffmeisteri; and the benthic midge: Glyptotendipes tokunagai) was installed to simulate the effects of benzyl chloride in real ecosystems. It was assumed that a river was exposed to benzyl chloride after a chemical accident. Subsequently, the responses of the above-mentioned species were observed. To the best of our knowledge, this is the first stream mesocosm study performed on benzyl chloride using indigenous Korean species to simulate chemical spills in Korea. Therefore, this study focused on evaluating the individual responses of each species when chemical spills occur and improving the understanding of different sensitivities among Korean species to chemicals. The present study intends to provide reliable and relevant ecotoxicological data, namely the no observed effect concentration (NOEC), for indigenous Korean species in real environments. Furthermore, hazard concentration 
(HC) was calculated using the NOEC for each species. This artificial stream mesocosm study can serve as a potential predictive tool for hazard/risk assessment of benzyl chloride.

\section{Materials and Methods}

\subsection{Artificial Stream Mesocosm System}

The artificial stream system consisted of five glass sections with a head tank, namely an upper riffle section, a lower run section, a pool section, a lower section, and a tail tank (Table 1). Each section was positioned to gradually decrease in height to reflect the characteristics of an actual stream. Dechlorinated tap water was passed through a membrane filter and a high-grade activated carbon filter, and introduced into the head tank at a rate of $5 \mathrm{~L} / \mathrm{min}$. To stabilize the artificial stream, the substrates were placed in each section and dechlorinated tap water was flowed through the system during a 30-day stabilization period. Test organisms (except periphyton algae) were introduced for acclimation during system stabilization. Details regarding each section of the artificial steam mesocosm are provided in Table 1.

Table 1. Details of each section of the artificial stream mesocosm system.

\begin{tabular}{|c|c|c|}
\hline Section & $\begin{array}{c}\text { Size }(\mathrm{cm}) \\
(\text { Width } \times \text { Length } \times \text { Depth })\end{array}$ & Substrate \\
\hline Head tank & $50 \times 100 \times 100$ & $\begin{array}{c}\text { Water } \\
\text { (80 cm depth) }\end{array}$ \\
\hline $\begin{array}{l}\text { Upper } \\
\text { Riffle section }\end{array}$ & $\begin{array}{c}30 \times 200 \times 10 \\
\text { (with slope approximately } 4.3 \% \text { ) }\end{array}$ & $\begin{array}{c}\text { Stone/tile } \\
(0.5 \mathrm{~cm} \text { depth for tile, approximately } \\
10 \mathrm{~cm} \text { depth for stone })\end{array}$ \\
\hline $\begin{array}{c}\text { Lower } \\
\text { Run section }\end{array}$ & $30 \times 200 \times 10$ & $\begin{array}{c}\text { Gravel } \\
(2-5 \mathrm{~cm} \text { depth })\end{array}$ \\
\hline Pool section & $30 \times 100 \times 40$ & $\begin{array}{c}\text { Water } \\
\text { (30 cm depth) }\end{array}$ \\
\hline Lower section & $40 \times 200 \times 20$ & $\begin{array}{l}\text { Sand/sediment } \\
\text { (10 cm depth) }\end{array}$ \\
\hline Tail tank & $40 \times 100 \times 50$ & $\begin{array}{c}\text { Water } \\
\text { (30 cm depth) }\end{array}$ \\
\hline
\end{tabular}

\subsection{Test Organisms}

The Organization for Economic Cooperation and Development (OECD) guidelines [29] recommend that microcosm and mesocosm studies should focus on taxonomic groups concerned with lower-tier risk assessment. Accordingly, we selected test species belonging to five important taxonomic groups, namely periphytic algae, the cladoceran M. macrocopa (Arthropoda, Branchiopoda), the worm L. hoffmeisteri (Annelida, Oligochaeta), the midge G. tokunagai (Arthropoda, Chironomidae), and the fish Z. platypus and A. chinensis (Table 2).

Both fish species (Z. platypus and A. chinensis), M. macrocopa and G. tokunagai are indigenous to and widely distributed in Korea. Kim et al. [30] mentioned that M. macrocopa is an appropriate surrogate species for assessing toxic effects because of its abundance in the agriculture environments of Korea, and it also has economic importance, as reproduction assays can be conducted in a short period owing to its short life cycle. The average life span of M. macrocopa is approximately $10 \mathrm{~d}$ [30] and it has been observed that individuals continued to grow until $12 \mathrm{~d}$, after which a steep decrease in their abundance was observed [31,32]. M. macrocopa is the most abundant cladoceran in Korea and the sensitivities of M. macrocopa and D. magna have been compared by several researchers $[30,33]$. Cho et al. [33] reported that $M$. macrocopa showed a higher sensitivity than D. magna for organic extracts of sediment from Korean streams. The mortality of M. macrocopa was $85 \%$ compared with the mortality of D. magna of $30 \%$. Moreover, Z. platypus was identified as the most abundant species on the Korean Peninsula [34] and has been used as a target 
indicator to assess regional ecological health $[35,36]$. G. tokunagai is distributed widely in urban streams throughout East Asia and has been recommended for use as a water quality indicator in Korea [37].

Table 2. Summary of test species.

\begin{tabular}{|c|c|c|c|c|c|c|}
\hline Section & Test Species & Age & $\begin{array}{l}\text { Acclimation } \\
\text { Period }\end{array}$ & $\begin{array}{l}\text { Number of } \\
\text { Individuals }\end{array}$ & Endpoint & Study Parameter \\
\hline $\begin{array}{c}\text { Upper } \\
\text { Riffle section }\end{array}$ & $\begin{array}{c}\text { Periphyton algae } \\
\text { (species not } \\
\text { classified) }\end{array}$ & $\begin{array}{l}30 \text { days growth } \\
\text { on tiles }\end{array}$ & $30 \mathrm{~d}$ & - & Growth & $\begin{array}{l}\text { Chlorophyll-a, dry } \\
\text { cell weight, quantum } \\
\text { yield }\end{array}$ \\
\hline $\begin{array}{c}\text { dower } \\
\text { Run section }\end{array}$ & Moina macrocopa & $\begin{array}{l}\text { Neonates } \\
(<24 \mathrm{~h})\end{array}$ & - & $\begin{array}{c}20 \text { individuals } \\
\text { (5/subreplicate, } \\
4 \text { subrep.) }\end{array}$ & $\begin{array}{l}\text { Survival, } \\
\text { fecundity }\end{array}$ & $\begin{array}{c}\text { Mortality of parents, } \\
\text { Number of living } \\
\text { offsprings }\end{array}$ \\
\hline Pool section & Zacco platypus & $\begin{array}{l}\text { Approximately } \\
2-3 \text { months } \\
(4-5 \mathrm{~cm} \text { in length })\end{array}$ & $14 \mathrm{~d}$ & 50 individuals & $\begin{array}{l}\text { Survival, } \\
\text { behavior, } \\
\text { growth }\end{array}$ & $\begin{array}{l}\text { Mortality, behavior } \\
\text { observation, length } \\
\text { and weight }\end{array}$ \\
\hline Lower section & $\begin{array}{l}\text { Glyptotendipes } \\
\text { tokunagai, } \\
\text { Limnodrilus } \\
\text { hoffmeisteri }\end{array}$ & $\begin{array}{c}\text { 2nd instar larvae } \\
\text { (G. tokunagai), } \\
\text { adults } \\
\text { (L. hoffmeisteri) }\end{array}$ & $\begin{array}{c}1 \mathrm{~d} \\
\text { (G. tokunagai) } \\
7 \mathrm{~d} \\
\text { (L. hoffmeisteri) }\end{array}$ & 240 individuals & Survival & $\begin{array}{c}\text { Number of survived } \\
\text { organisms }\end{array}$ \\
\hline Tail tank & $\begin{array}{l}\text { Aphyocypris } \\
\text { chinensis }\end{array}$ & $\begin{array}{l}\text { Approximately } \\
\text { 2-3 months }\end{array}$ & $14 \mathrm{~d}$ & 50 individuals & $\begin{array}{l}\text { Survival, } \\
\text { behavior, } \\
\text { growth }\end{array}$ & $\begin{array}{l}\text { Mortality, behavior } \\
\text { observation, length } \\
\text { and weight }\end{array}$ \\
\hline
\end{tabular}

In this study, the test species were introduced into each section for stabilization for 1-30 d before chemical exposure. Pebbles with periphytic algae were sampled from a natural river and then placed on top of the tile section to facilitate attachment of the algae onto the tiles for $30 \mathrm{~d}$ (three rows of 20 non-glazed tiles per tank), respectively. Acclimation for periphyton algae began at the same time as system stabilization and other species were introduced into the system in sequence. Z. platypus and A. chinensis (standard length: 3-4 cm) were obtained from the Institute of Biodiversity Research (Jeonjusi, Korea) and acclimated for two weeks prior to exposure in each section (pool and tail tank). Approximately, 240 2nd instar larvae of G. tokunagai, which were cultured in the laboratory, and approximately 240 L. hoffmeisteri adults were obtained from an aquatic animal supplier (Alpha Fish, Yeosu-si, Korea) Both species were introduced into the lower section with sand/sediment. G. tokunagai were acclimated for one day and L. hoffmeisteri were acclimated for seven days before staring of chemical exposure. M. macrocopa were cultured in the laboratory and five animals (age: $<24 \mathrm{~h}$ ) per replicate were introduced into a glass chamber with a mesh cover. Newly hatched M. macrocopa were introduced into the system without any acclimation period. After the acclimation period, all species were exposed to benzyl chloride during the same period of $22.5 \mathrm{~h}$ but then organisms were observed during different post-exposure periods. The information for each test species is summarized in Table 2.

\subsection{Test Chemical and Exposure Scenario}

Benzyl chloride used in this study was purchased from Sigma-Aldrich (CAS No.: 100-44-7, purity: $98.5 \%$ ). Its solubility was $525 \mathrm{mg} / \mathrm{L}$ at $25^{\circ} \mathrm{C}$, log Kow was 2.30 , and vapor pressure was $123 \mathrm{mmHg}$ at $25^{\circ} \mathrm{C}$ [38]. The exposure scenario, involved a simulated case of chemical leakage into the river upstream, from a chemical tank truck. An alternative scenario selection method was based on the Technical Guidelines on Accident Scenario Selection of the National Institute of Chemical Safety [39]. A worst-case scenario of acute toxic effects of $100 \%$ mortality of organisms was excluded. In the alternative scenario, the end-point concentration referred to the concentration that affects the environment after the chemical is released from the source. The endpoint concentration concept was used to calculate the certain concentration at the point at which the chemical that was discharged from the tank entered the water system. In addition, it was assumed that a 
certain concentration was maintained for a while in this study. Exposure concentrations were calculated using three acute toxicity $\left(\mathrm{LC}_{50}\right)$ values from our preliminary acute toxicity test (unpublished data) in accordance with the endpoint concentration criteria of the alternative scenario. The highest concentration was determined based on this concept, and the lower concentrations were determined to give factor of 2 . The exposure time to maintain the concentration was calculated using the amount and flow rate of the leaked chemicals it was $22.5 \mathrm{~h}$ in this study.

\subsection{Artificial Stream Mesocosm Study}

\subsubsection{Test Chemical Exposure}

Four artificial stream mesocosms (one control and three treatments) established simultaneously. The exposure concentrations of benzyl chloride were 1,2 , and $4 \mu \mathrm{L} / \mathrm{L}$, and the exposure time was $22.5 \mathrm{~h}$ based on the leaked chemical amount. Aliquots of $5 \mu \mathrm{L}, 10 \mu \mathrm{L}$ and $50 \mu \mathrm{L}$ of benzyl chloride were released directly into water $(5 \mathrm{~L} / \mathrm{min})$ using a syringe pump for each concentration. Benzyl chloride was detected after $1 \mathrm{~h}$ from the surface water of all systems and the measured concentrations were $15.5-48.6 \%$ of nominal concentrations after $5 \mathrm{~h}$. After the $22.5 \mathrm{~h}$ of exposure duration, only clean dechlorinated tap water was introduced into the system during the 28-day post-exposure period.

\subsubsection{Observation of Test Organisms}

A summary of test organisms is presented in Table 2.

- Periphyton algae

To identify the effect on the algae biomass and photosynthesis, chlorophyll-a concentration, dry cell weight (DCW) and quantum yield were measured in this study. Periphyton algae were collected from the tiles (surface area per tile: $75.69 \mathrm{~cm}^{2}$ ) in the riffle section on days $-1,0,1,7,14,21$, and 28 . Four tiles were randomly sampled from each mesocosm; subsequently, periphyton was scraped using a brush and mixed with distilled water to determine the chlorophyll-a concentration, dry cell weight and quantum yield. Chlorophyll-a concentration was measured using a standard method [40,41] and dry cell weight and quantum yield were measured according to the procedures used in a previous study [42].

\section{- Crustacea}

To investigate the survival and reproduction capacity of $M$. macrocopa, glass chambers were removed from each stream mesocosm daily. The chambers were returned to the mesocosm after the surviving parents were observed and the number of offspring was counted over $14 \mathrm{~d}$.

\section{- Fish}

Fifty individuals of Z. platypus and A. chinensis were introduced in the pool and tail sections, respectively. Fish were maintained within each section because the depth did not allow the fish to swim to another section and also each section of the mesocosm system was designed to gradually decrease in height. Mortality and abnormalities (e.g., abnormal swimming behavior, and loss of equilibrium) of fish for each stream mesocosm were recorded daily. For determination of growth during the test period, the total length (using digital Vernier calipers) and wet weight of all surviving fish were measured on day 30 to compare the condition factor $(\mathrm{K})$. Fulton's condition factor was calculated using the following formula: $\mathrm{K}=100 \times \mathrm{W}$ (wet weight, g) $/ \mathrm{L}^{3}$ (total length, $\mathrm{mm}$ ) [43].

\section{- Chironomidae and freshwater red worm}

Four subsamples $(9 \mathrm{~cm}$ in diameter and $4 \mathrm{~cm}$ in depth) were collected from the lower sediment section to observe their effects on G. tokunagai and L. hoffmeisteri. The number of surviving individuals was counted in each subsample on day 0 (before chemical exposure) and on days $1,7,14,21$, and 28 . Dry weights of L. hoffmeisteri in each subsample were measured after drying for $24 \mathrm{~h}$ at $60^{\circ} \mathrm{C}$. 


\subsubsection{Water Parameters and Chemical Analysis}

Water temperature, dissolved oxygen (DO), $\mathrm{pH}$, and conductivity of each mesocosm system were measured on day 0 (before chemical exposure) and on days $1,7,14,21,28$, and 30. The temperature, $\mathrm{pH}, \mathrm{DO}$, and conductivity values were $22.8-27.9{ }^{\circ} \mathrm{C}$ (Table S1), 7.20-8.98, 7.82-9.92 mg/L, and 72-86 $\mu \mathrm{S} / \mathrm{cm}$, respectively (Instrument: Orion Star A211, Thermo Scientific). The water temperature was measured in the morning (9:00-10:00) or in the afternoon (15:00-17:00). This test was conducted from August to September; therefore, some variability in temperature was observed, but the temperature between systems and sections was similar on the same day. Other parameters, such as hardness (113-116 mg/L), total organic carbon (TOC) $(0.5-1.8 \mathrm{mg} / \mathrm{L}$ ), residual chlorine (not detected, $<0.02 \mathrm{mg} / \mathrm{L}$ ), and ammonia (not detected, $<0.01 \mathrm{mg} / \mathrm{L}$ ) in the dechlorinated tap water used in this artificial stream mesocosm were monitored quarterly (Korea Testing and Research Institute, Changwon-si, Korea), to determine whether the water quality was acceptable for aquatic organisms [44]. The benzyl chloride concentrations of surface water in each section of the system were measured after 1,5 and $22.5 \mathrm{~h}$ of chemical exposure. Additionally, the concentration was measured at $48 \mathrm{~h}$ after exposure to check for residues of benzyl chloride. All samples were measured immediately after pre-treatment using high-performance liquid chromatography (column: Hydrosphere C18, $150 \times 4.6 \mathrm{~mm}, 5 \mu \mathrm{m}$, Mobile phase: 80/20 (ACN/water)).

\subsection{Animal Welfare and Institutional Animal Care and Use Committee}

Fish were handled according to the standard operating procedures of the Gyeongnam Department of Environmental Toxicology and Chemistry, Korea Institute of Toxicology (KIT), and the study plan. All procedures in this study complied with the Animal Welfare Act and the Guide for the Care and Use of Laboratory Animals. This study was reviewed and assessed by the Institutional Animal Care and Use Committee (IACUC) of the Gyeongnam Department of Environmental Toxicology and Chemistry, KIT. The study was approved by the IACUC (approval number 2009-0007).

\subsection{Statistical Analyses}

The experimental analysis results of the data collected from the treatments and the control were evaluated using analysis of variance. Normality and homogeneity of variance test were determined using the Shapiro-Wilk test and Levene's test. If these were satisfied, a one-way analysis of variance and post-hoc analysis (Dunnett's test) were performed. Based on the statistical analysis, NOEC (No Observed Effected Concentration) was determined using the CETIS ${ }^{\mathrm{TM}}$ v. 1.8.7.16 (Tidepool Scientific Software, McKinleyville, CA, USA). The benzyl chloride concentration for the NOEC calculation was based on the mean measured concentration in each section.

\subsection{Estimation of Hazard Concentration}

HC (hazardous concentration) values were generated from the determination of the species sensitivity distribution (SSD). SSD analysis was performed using the Chemical Aquatic Fate and Effects (CAFE) database (version 1.2, National Oceanic and Atmospheric Administration, Office of Response and Restoration, Emergency Response Division, Seattle, WA, USA). The CAFE database is a software program and it is possible to estimate the fate and effects of thousands of chemicals, oils, and dispersants. The CAFE database was developed to support the assessment of chemical spills in aquatic environments and it shows the estimated short exposure risk using fate and effect data obtained from multiple databases [45].

In this study, two SSD curves for benzyl chloride were generated and compared using the CAFE program to estimate the ecological risks after a benzyl chloride spill. For the SSD created using its own database, there were few acute data points for benzyl chloride (data for only two species were available in the database), hence, it was not possible to create an SSD curve containing toxicity data. Therefore, an SSD curve was created based 
on interspecies correlation estimate (ICE) modeling based on existing data for D. magna. This program also allows users to add data; therefore, another SSD was generated using the NOEC values obtained from this mesocosm study for comparison with the integral CAFE toxicity data.

\section{Results and Discussion}

\subsection{Benzyl Chloride Concentration in Water}

Based on the physicochemical properties of benzyl chloride, the fraction of distribution was estimated using Level III fugacity modelling by EpiWin (US EPA) and the results showed that benzyl chloride remains predominantly in the water after its release (Table 3). Benzyl chloride was released into the water directly in this study, therefore it was expected that most of the benzyl chloride was distributed in the water according to this estimation result. However, hydrolysis could be the primary removal mechanism because the hydrolysis half-life (DT50) of benzyl chloride is $9.5 \mathrm{~h}$ at $\mathrm{pH} 7$ and $25^{\circ} \mathrm{C}$ [46].

Table 3. Estimated distribution of benzyl chloride after its release in water.

\begin{tabular}{ccccc}
\hline \multirow{2}{*}{ Released to } & \multicolumn{4}{c}{ Fraction of Distribution to Each Medium (\% of Total) } \\
\cline { 2 - 5 } & Air & Water & Soil & Sediment \\
\hline Water $(100 \%)$ & 7.9 & 90 & 0.16 & 1.6 \\
\hline
\end{tabular}

In addition, an estimated Koc value of 100 determined from a logKow of 2.3 [47] indicated that benzyl chloride would not be adsorbed into the soil and sediment. Volatilization from the water surface was expected based on an estimated Henry's Law constant of $4.12 \times 10^{-4} \mathrm{~atm} \cdot \mathrm{m}^{3} / \mathrm{mol}$, derived from a high vapor pressure of $163.9 \mathrm{~Pa}$ [48]. An estimated bioconcentration factor of $18 \mathrm{~L} / \mathrm{kg}$ (calculated using log Kow 2.3) and biomagnification factor of $1 \mathrm{~kg} / \mathrm{kg}$ (calculated using the default value of $\log$ Kow that is $<4.5$ ) indicated that the potential bioaccumulation of aquatic organisms was low [46].

Benzyl chloride was directly exposed to the water in this study, and most of the dissolved benzyl chloride and the degraded product remained in the water phase. The mean measured concentrations until the termination of chemical exposure $(22.5 \mathrm{~h})$ in each section are summarized in Table 4. Constant concentrations of water were maintained during exposure; however, most of the benzyl chloride could be evaporated into the air. After exposure, benzyl chloride rapidly diluted in the water, and was not detected in any section after $48 \mathrm{~h}$. The mean measured concentration of each section was used to calculate the NOEC values for each species. However, to simplify, the concentrations in figures, tables and descriptions were expressed as nominal concentrations, as the real concentration varied in time and between sections.

Table 4. Mean measured concentration of benzyl chloride in water in each section.

\begin{tabular}{|c|c|c|c|}
\hline \multirow{2}{*}{ Section } & \multicolumn{3}{|c|}{ Mean Measured Concentration $( \pm \mathrm{SD})(\mu \mathrm{L} / \mathrm{L})$} \\
\hline & $1 \mu \mathrm{L} / \mathrm{L}$ & $2 \mu \mathrm{L} / \mathrm{L}$ & $4 \mu \mathrm{L} / \mathrm{L}$ \\
\hline Head Tank & $0.29 \pm 0.17$ & $0.58 \pm 0.32$ & $1.01 \pm 0.08$ \\
\hline $\begin{array}{l}\text { Upper Riffle section } \\
\text { (Stone/tile) }\end{array}$ & $0.29 \pm 0.17$ & $0.41 \pm 0.41$ & $0.76 \pm 0.33$ \\
\hline $\begin{array}{l}\text { Lower Run section } \\
\text { (Gravel) }\end{array}$ & $0.28 \pm 0.15$ & $0.52 \pm 0.33$ & $0.98 \pm 0.04$ \\
\hline Pool section & $0.27 \pm 0.14$ & $0.45 \pm 0.29$ & $0.85 \pm 0.09$ \\
\hline $\begin{array}{l}\text { Lower section } \\
\text { (Sand/sediment) }\end{array}$ & $0.25 \pm 0.13$ & $0.39 \pm 0.26$ & $0.74 \pm 0.13$ \\
\hline Tail tank & $0.19 \pm 0.13$ & $0.27 \pm 0.22$ & $0.54 \pm 0.23$ \\
\hline
\end{tabular}




\subsection{Effect of Test Organisms}

- Periphyton algae

In this study, the chlorophyll concentrations in $2 \mu \mathrm{L} / \mathrm{L}$ and $4 \mu \mathrm{L} / \mathrm{L}$ treatments (mean measured concentration of the tile section: 0.41 and $0.76 \mu \mathrm{L} / \mathrm{L}$, respectively) were lower until day seven, after which they gradually increased, with values ranging above those of the control (Figure 1a). However, interestingly, the quantum yield increased in the control, whereas it decreased in the 2 and $4 \mu \mathrm{L} / \mathrm{L}$ treatments from day one (Figure 1b). Chlorophyll is a useful indicator of photosynthesis; however, Zou and Zhang [49] recommended quantum yield measurements for samples under natural conditions because of variation problems. The results indicated that benzyl chloride was assumed to affect the photosynthetic efficiency, although the chlorophyll concentration was not diminished.

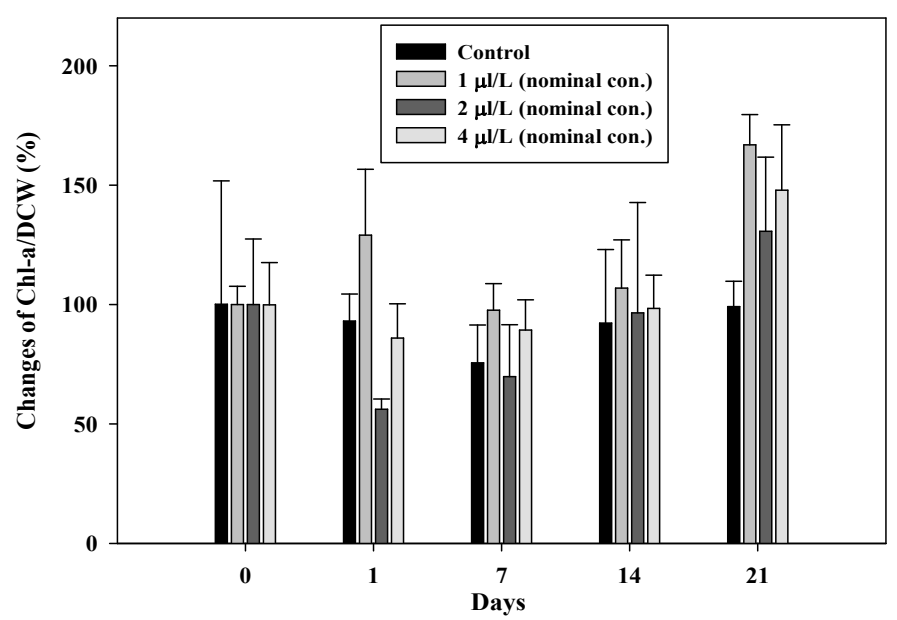

(a)

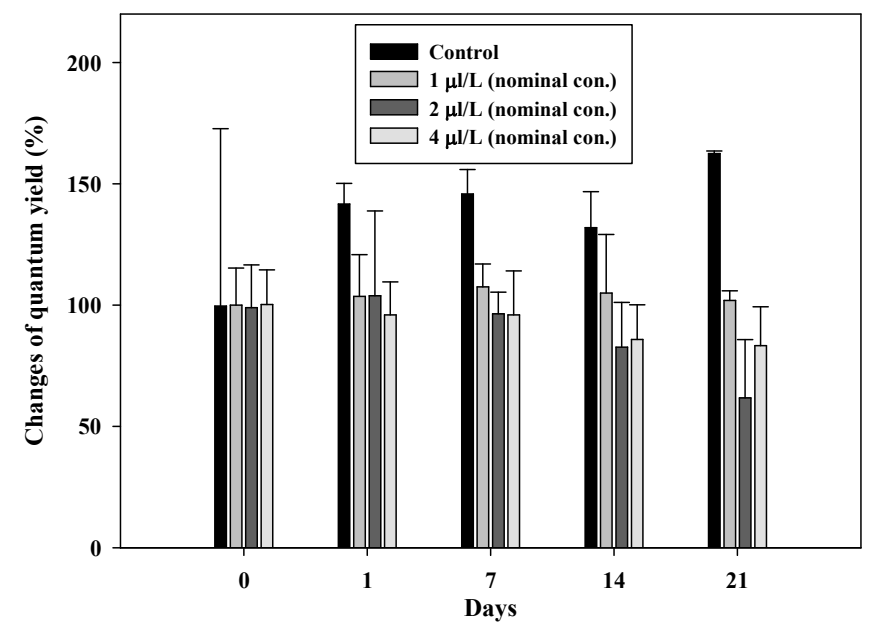

(b)

Figure 1. Changes in terms of (a) chlorophyll-a/dry cell weight and (b) quantum yield.

\section{- Crustacea}

The total number of offspring and the cumulative number of offspring per surviving female of M. macrocopa for $14 \mathrm{~d}$ are shown in Figure 2 and Table 5. The overall survival rate was determined on day 12 because the number of surviving individuals in all treatments groups (including the control) also decreased after $12 \mathrm{~d}$. The survival rate of $M$. macrocopa decreased in all three mesocosm systems, and mortality in the $4 \mu \mathrm{L} / \mathrm{L}$ treatment group (mean measured concentration of gravel section: $0.98 \mu \mathrm{L} / \mathrm{L}$ ) increased remarkably from day two, after which all organisms were dead. NOEC values were $0.28 \mu \mathrm{L} / \mathrm{L}$ for $1-7 \mathrm{~d}$ and $0.52 \mu \mathrm{L} / \mathrm{L}$ for $8-12 \mathrm{~d}$ based on the mean measured concentration. According to the ECOTOX database [50], the lowest acute toxicity value (24 h-EC50) of D. magna was $1.3 \mathrm{mg} / \mathrm{L}$. Based on this value and the findings of this study, M. macrocopa was found to be more sensitive to benzyl chloride than the other standard species.

Reproduction initiated on day five in all mesocosm systems, and there was no difference in the initial reproductive age between the treatment group. The total number of offspring decreased in the $2 \mu \mathrm{L} / \mathrm{L}$ treatment group (mean measured concentration: $0.58 \mu \mathrm{L} / \mathrm{L}$ ); however, the cumulative number of offspring based on surviving females decreased in the $4 \mu \mathrm{L} / \mathrm{L}$ treatment group (mean measured concentration: $0.98 \mu \mathrm{L} / \mathrm{L}$ ). The decrease in the number of offspring in the former mesocosm could have been caused by mortality of parents because the daily average reproduction rate per surviving female (Table 5) showed that there was no significant difference in all between the mesocosm systems. Further, the NOEC was $0.52 \mu \mathrm{L} / \mathrm{L}$ for survival rate and $0.28 \mu \mathrm{L} / \mathrm{L}$ for reproduction $(0.98 \mu \mathrm{L} / \mathrm{L}$ for reproduction rate/surviving female/day). 


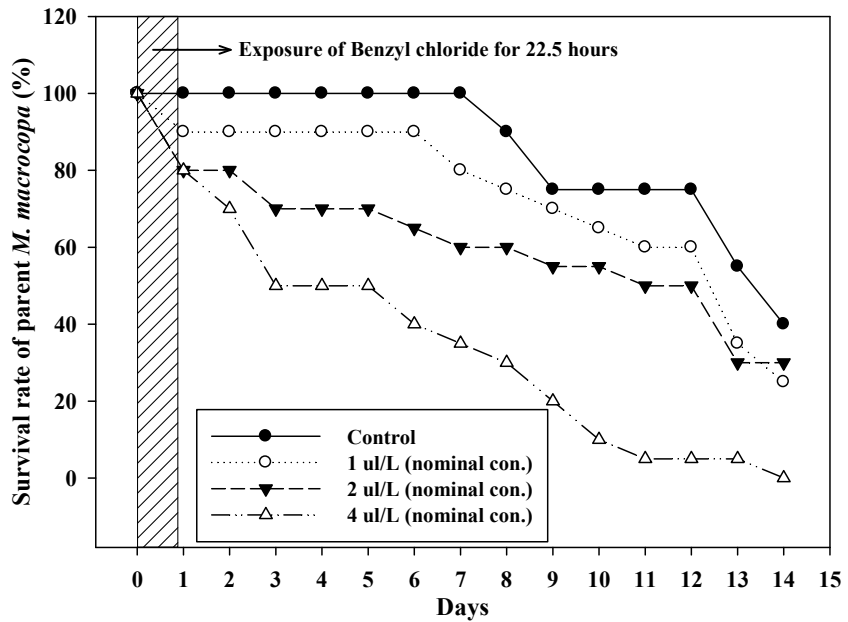

(a)

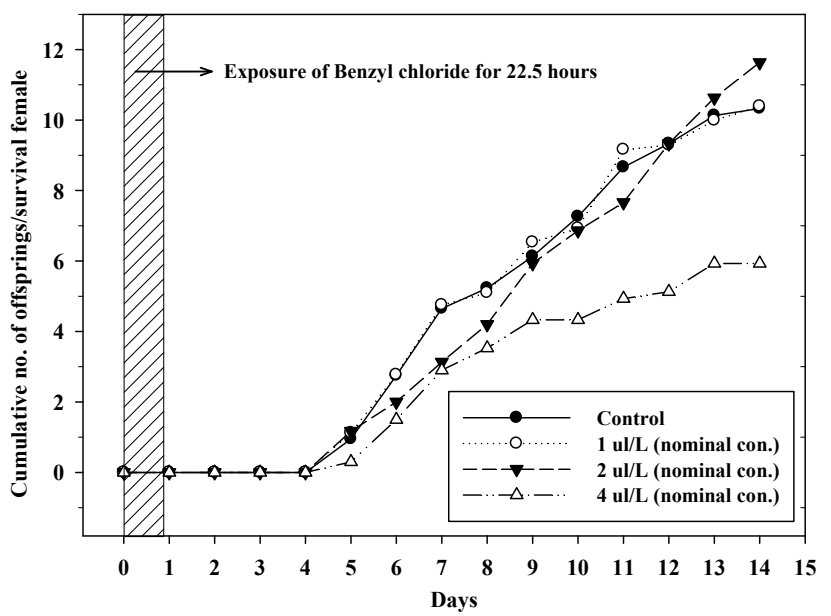

(b)

Figure 2. (a) Survival rate (\%) and (b) cumulative number of $M$. macrocopa offspring.

Table 5. M. macrocopa survival rate after exposure to different concentrations of benzyl chloride in stream mesocosms.

\begin{tabular}{cccc}
\hline $\begin{array}{c}\text { Nominal } \\
\text { Concentration } \\
(\mu \mathrm{L} / \mathrm{L})\end{array}$ & $\begin{array}{c}\text { a Survival Rate } \\
( \pm \text { SD) }(\%)\end{array}$ & $\begin{array}{c}\text { a }) \\
\text { Total No. of } \\
\text { Offspring }\end{array}$ & $\begin{array}{c}\text { Average Offspring/ } \\
\text { Surviving Females/Day } \\
( \pm \text { SD) }\end{array}$ \\
\hline $\begin{array}{c}\text { Control } \\
1\end{array}$ & $75.0 \pm 25.0$ & 159 & $1.03 \pm 0.51$ \\
2 & $60.0 \pm 22.4$ & 142 & $1.04 \pm 0.71$ \\
4 & $50.0 \pm 25.0$ & $104^{*}$ & $1.16 \pm 0.31$ \\
\hline
\end{tabular}

${ }^{*}$ Significant differences $(p<0.05) .{ }^{a}$ based on the data at day 12 .

- Fish

The mortality of $A$. chinensis did not occur owing to toxicity, and no specific toxicity symptoms were observed in any of the mesocosm systems within $30 \mathrm{~d}$. However, $Z$. platypus mortality was $17.5 \%$ in the $4 \mu \mathrm{L} / \mathrm{L}$ treatment group, and toxicity symptoms such as loss of equilibrium and abnormal swimming behavior were observed for approximately $13 \mathrm{~d}$, even when the organisms were no longer exposed to benzyl chloride. After $11 \mathrm{~d}$, the organisms showed increased activity, and they appeared to recover after $15 \mathrm{~d}$ (Figure 3).

The acute toxicity data of the fish species (Table 6) showed that these species were more sensitive than other international standard species, such as Pimephales promelas and Danio rerio (toxicity range of 3-16 $\mathrm{mg} / \mathrm{L}$ ) according to the ECOTOX database [44]. In this study, Z. platypus showed delayed toxic symptoms with a recovery pattern after the termination of the chemical exposure. A. chinensis did not show any toxic behaviors, thus, Z. platypus can potentially be used as a sentinel species to study the effects of chemicals on fish. Further, no significant differences were observed in the condition factors of the two fish species on day 30 . 


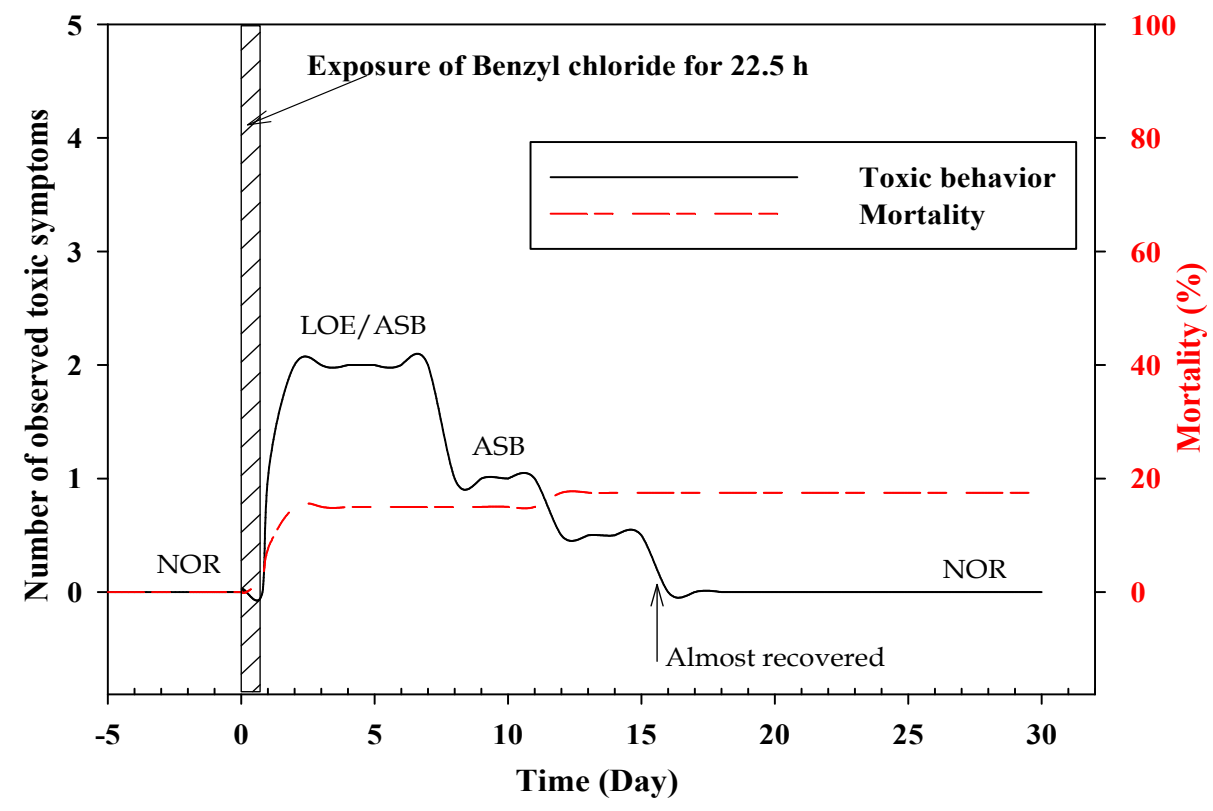

Figure 3. Survival rate and toxic behaviors of Z. platypus in the $4 \mu \mathrm{L} / \mathrm{L}$ benzyl chloride. (LOE: loss of equilibrium, ASB: abnormal swimming behavior, NOR: normal).

Table 6. Survival rates and condition factors in Z. platypus and A. chinensis, following benzyl chloride exposure.

\begin{tabular}{ccccc}
\hline \multirow{2}{*}{$\begin{array}{c}\text { Nominal Concentration } \\
(\mu \mathrm{L} / \mathrm{L})\end{array}$} & \multicolumn{2}{c}{ Survival Rate $(\%)$} & \multicolumn{2}{c}{ Condition Factor $(\mathrm{K})( \pm \mathrm{SD})$} \\
\cline { 2 - 5 } & A. chinensis & Z. platypus & A. chinensis & Z. platypus \\
\hline Control & 100 & 97.5 & $1.09 \pm 0.15$ & $1.05 \pm 0.26$ \\
1 & 100 & 100 & $1.10 \pm 0.16$ & $0.92 \pm 0.18$ \\
2 & 97.5 & 100 & $1.09 \pm 0.23$ & $0.92 \pm 0.19$ \\
4 & 100 & 82.5 & $1.05 \pm 0.19$ & $0.95 \pm 0.21$ \\
\hline
\end{tabular}

- Chironomidae and freshwater red worm

The average numbers of $G$. tokunagai and L. hoffmeisteri individuals per sample are shown in Figures 4 and 5. After benzyl chloride exposure for $22.5 \mathrm{~h}$, a few G. tokunagai individuals were observed in the $4 \mu \mathrm{L} / \mathrm{L}$ treatment (mean measured concentration: $0.74 \mu \mathrm{L} / \mathrm{L}$ ) and none were observed after seven days. In the $1 \mu \mathrm{L} / \mathrm{L}$ and $2 \mu \mathrm{L} / \mathrm{L}$ treatments (mean measured concentration: $0.25 \mu \mathrm{L} / \mathrm{L}$ and $0.39 \mu \mathrm{L} / \mathrm{L}$, respectively), the number of individuals decreased drastically from day seven; however, $4-5$ individuals continued to be observed in the control until day 28. It was assumed that almost all individuals introduced into the mesocosm systems, except the control, were dead before emergence because adults were not observed until day 28, and the developmental time (from larva to adult) of G. tokunagai is approximately $26-38 \mathrm{~d}$ [32].

Moreover, on average, 9-10 individuals of $L$. hoffmeisteri were observed per subsample in all mesocosm systems, with no toxic effects (Figure 5a). The weight of L. hoffmeisteri decreased in all systems after seven days, with no significant difference between the control and the treatments (Figure $5 b$ ). 


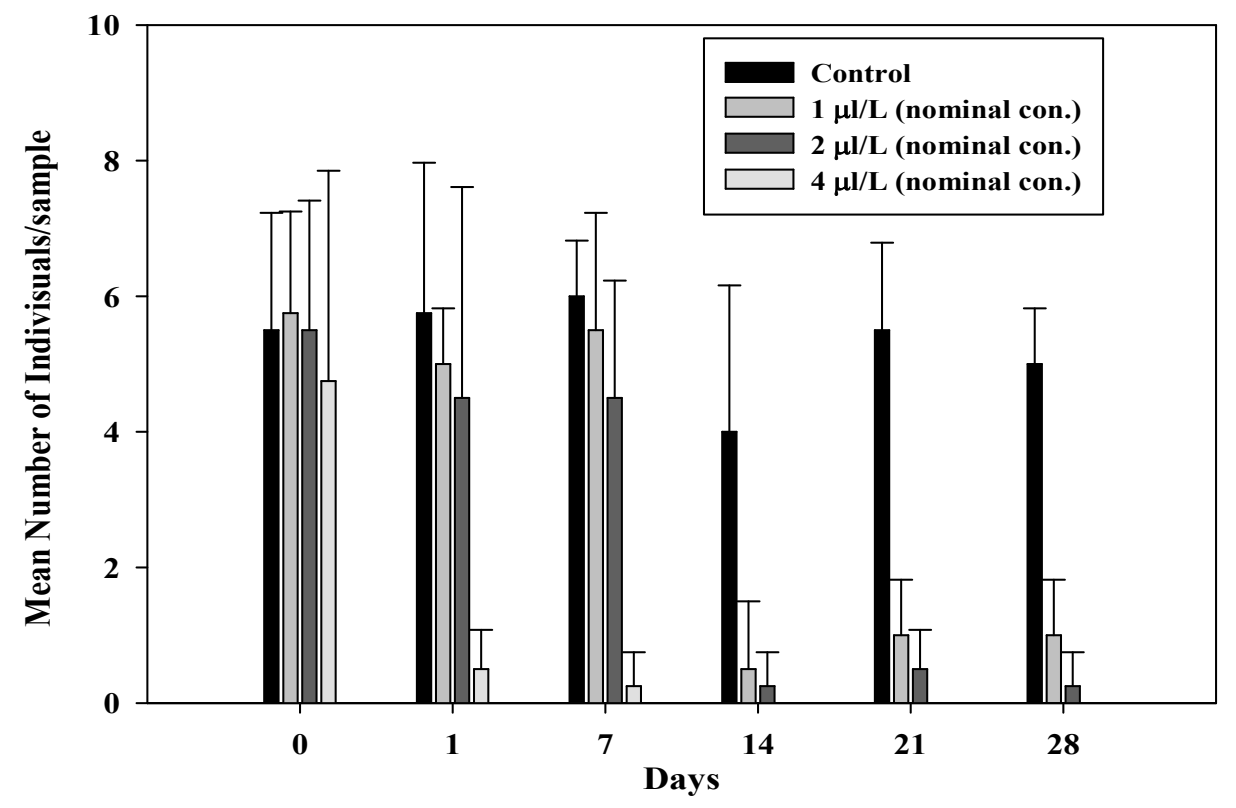

Figure 4. Mean number of G. tokunagai individuals/sample after benzyl chloride exposure.

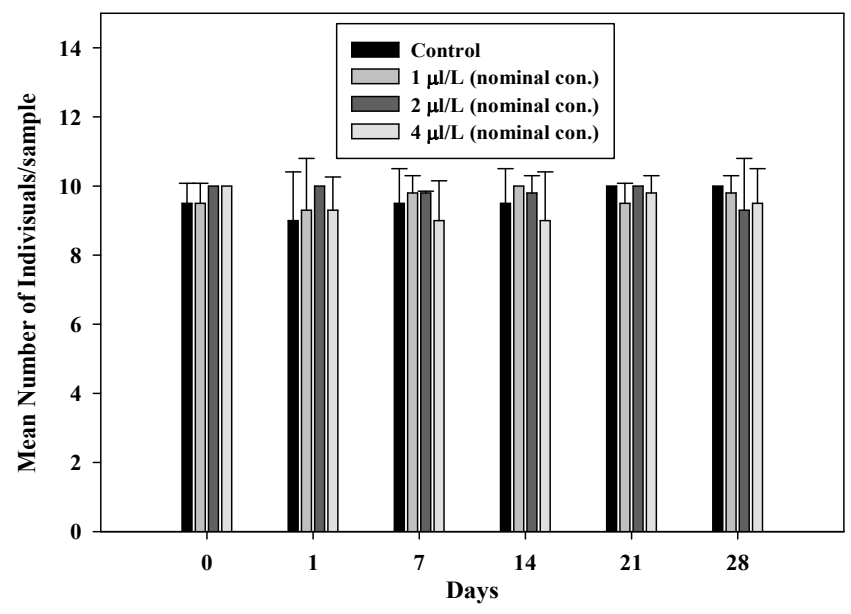

(a)

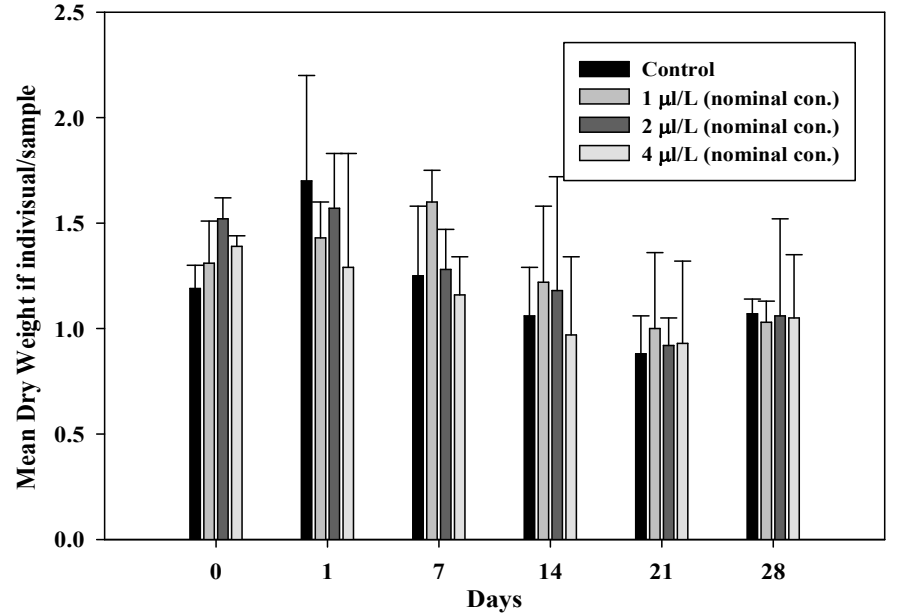

(b)

Figure 5. (a) Mean number and (b) dry weight of L. hoffmeisteri individuals/sample after benzyl chloride exposure.

\subsection{Estimation of Hazard Concentration}

NOECs for each species are provided in Table 7 and were used for SSD analysis. Two SSD curves created using the CAFE program, using its own database and our mesocosm study data, are shown in Figure 6.

The SSD constructed using ICE modeling data showed that the toxicity was primarily located in the moderately toxic to slightly toxic range; however, the SSD acquired through our mesocosm data showed a highly toxic range. Using these SSD curves, the estimated 5th percentile HC5 values were calculated as $798 \mu \mathrm{g} / \mathrm{L}$ for the ICE modeling data and $94 \mu \mathrm{g} / \mathrm{L}$ for our study data.

Table 7. No observed effect concentration (NOECs) for each species.

\begin{tabular}{cccccc}
\hline \multicolumn{5}{c}{$\operatorname{NOEC}(\mu \mathrm{L} / \mathrm{L})$} \\
\hline G. tokunaga & M. macrocopa & $\begin{array}{c}\text { Periphyton } \\
\text { Algae }\end{array}$ & A. chinensis & Z. platypus & L. hoffmeisteri \\
\hline 0.25 & 0.28 & 0.29 & 0.54 & 0.85 & 0.98 \\
\hline
\end{tabular}




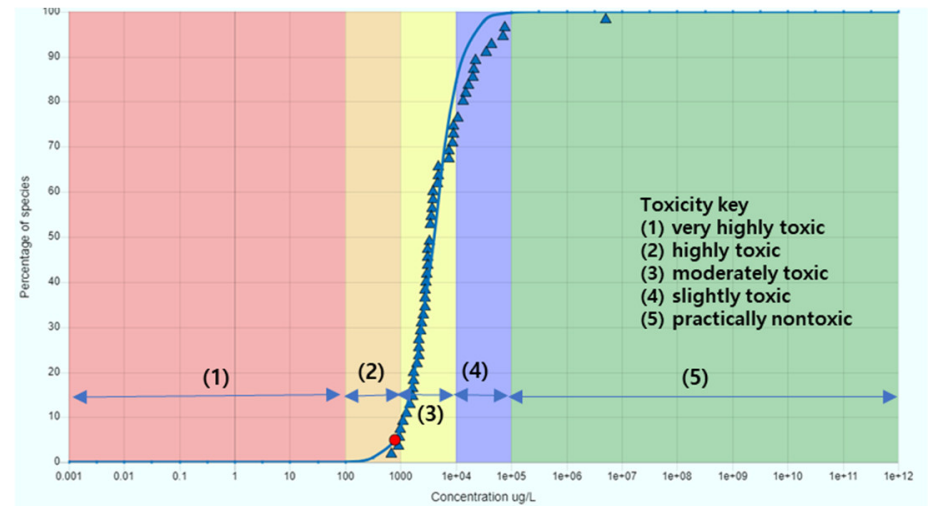

(a)

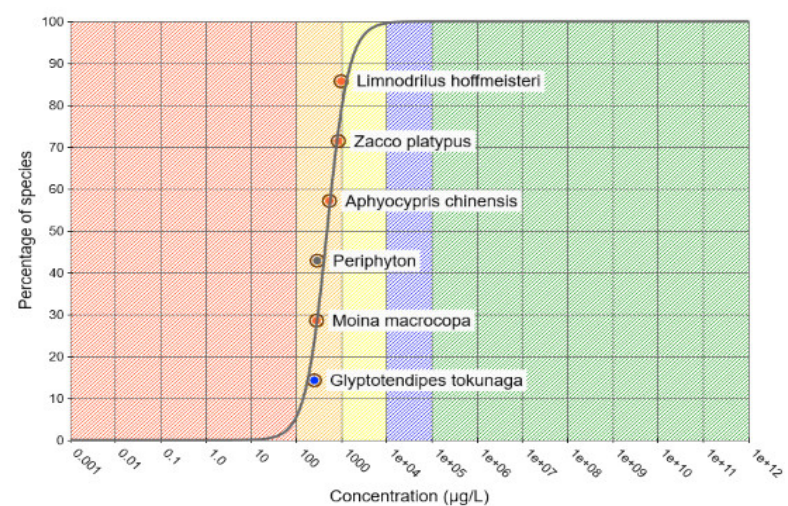

(b)

Figure 6. Species sensitivity distribution (SSD) curves with toxicity data. (a) SSD (ICE modeling data) and (b) SSD (mesocosm study data).

\section{Conclusions}

To our knowledge, this is the first artificial stream mesocosm study simulating a benzyl chloride spill that demonstrated toxic effects on indigenous Korean aquatic species. The short-term exposure resulted in NOEC values ranging from 0.25 to $0.98 \mu \mathrm{L} / \mathrm{L}$. The responses of the test species to benzyl chloride showed that G. tokunaga and M. macrocopa had NOECs ranging from 0.25 to $0.28 \mu \mathrm{L} / \mathrm{L}$ and were more sensitive than the other species, and that M. macrocopa, G. tokunagai, and Z. platypus showed delayed toxic effects. Although there was no evidence regarding the mechanisms causing delayed effects, the toxicity of benzyl chloride to aquatic organisms was evident.

According to the SSD analysis, all the Korean indigenous species selected for this study showed high sensitivity and toxicity to benzyl chloride compared to the international standard species. The findings indicated that some species can be suggested as sentinel species or environmental indicators because of their high sensitivity to benzyl chloride. The individual toxic effects of chemical spills were investigated successfully in this study, and future studies should include measurements of toxicity at the population level to simulate natural conditions more efficiently. In conclusion, this artificial stream mesocosm study can assist in risk assessments for aquatic ecosystems after chemical spills and could provide substantial evidence to establish different criteria for ecological risk assessment because some species were particularly sensitive to benzyl chloride.

Supplementary Materials: The following are available online at https:/ /www.mdpi.com/article/10 .3390 /toxics $9120347 /$ s1, Table S1: Water temperature $\left({ }^{\circ} \mathrm{C}\right)$.

Author Contributions: Conceptualization, D.-H.Y.; Data curation, S.-H.P., D.-W.K. and W.N.; Formal analysis, S.-Y.K., S.-H.P., D.-W.K. and W.N.; Investigation, S.-J.L., H.-J.J., J.-B.P., Y.-J.G. and J.-W.P.; Writing-original draft, S.-Y.K.; Writing-review \& editing, D.-H.Y. All authors have read and agreed to the published version of the manuscript.

Funding: This research was funded by the Korea Ministry of Environment (MOE).

Institutional Review Board Statement: The study was conducted according to the standard operating procedures of the Gyeongnam Department of Environmental Toxicology and Chemistry, Korea Institute of Toxicology (KIT), and the study plan. All procedures in this study complied with the Animal Welfare Act and the Guide for the Care and Use of Laboratory Animals. This study was reviewed and approved by the Institutional Animal Care and Use Committee (IACUC) of KIT (KIT-IACUC) (approval code: 2009-0007, date of approval: 29 November 2020).

Informed Consent Statement: Not applicable.

Data Availability Statement: Not applicable. 
Acknowledgments: This work was supported by the Korea Environment Industry and Technology Institute (KEITI) through "The Chemical Accident Prevention Technology Development Project" funded by the Korea Ministry of Environment (MOE) (project number: 2016001970002).

Conflicts of Interest: The authors declare no conflict of interest.

\section{References}

1. U.S. EPA. Health And Environmental Effects Profile for Benzyl Chloride; EPA/600/X-86/148 (NTIS PB88219449); U.S. Environmental Protection Agency: Washington, DC, USA, 1986.

2. HIS Markit, Chemical Economics Handbook, Benzyl Chloride. 2018. Available online: https://ihsmarkit.com/products/benzylchloride-chemical-economics-handbook.html (accessed on 12 March 2021).

3. Huh, D.-A.; Huh, E.-H.; Byeon, S.-H.; Sohn, J.-R.; Moon, K.W. Development of accident probability index using surrogate indicators of chemical accidents in chemical plants. Int. J. Environ. Res. Public Health 2019, 16, 3271. [CrossRef]

4. FACTS Hazardous Materials Accidents Knowledge Base. Available online: http://www.factsonline.nl/accidents/\%205405/9173 8_BENZYL\%20CHLORIDE/chemical-accidents-with-benzyl-chloride (accessed on 11 January 2021).

5. You, J.; Chung, Y.-J. Case Analysis of the Harmful Chemical Substances' Spill. Fire Sci. Eng. 2014, 28, 90-98. [CrossRef]

6. National Institute of Chemical Safety, Chemical Substance Information System. Available online: https://icis.me.go.kr/main.do (accessed on 12 March 2021).

7. Lee, K.; Kwon, H.-M.; Cho, S.; Kim, J.; Moon, I. Improvements of safety management system in Korean chemical industry after a large chemical accident. J. Loss Prev. Process Ind. 2016, 42, 6-13. [CrossRef]

8. Chae, Y.; Cui, R.; Moon, J.; An, Y.-J. Ecological hazard assessment of methyl ethyl ketone using the species sensitivity distribution approach in a soil ecosystem. J. Hazard. Mater. 2018, 360, 490-497. [CrossRef] [PubMed]

9. Hong, H.J.; Park, S.H.; Lim, H.B.; Lee, C.M. Development on Health Risk Assessment Method for Multi-Media Exposure of Hazardous Chemical by Chemical Accident. Int. J. Environ. Res. Public Health 2020, 17, 3385. [CrossRef] [PubMed]

10. McReady, D.; Williams, J.B. Risk Assessment for a Chemical Spill into a River. J. Risk Anal. Crisis Response 2013, 3, 116-126. [CrossRef]

11. Lamberti, G.A.; Steinman, A.D. Research in Artificial Streams: Applications, Uses, and Abuses. J. N. Am. Benthol. Soc. 1993, 12, 313-384. [CrossRef]

12. Solomon, K.R. Overview of Recent Developments in Ecotoxicological Risk Assessment. Risk Anal. 1996, 16, 627-633. [CrossRef]

13. Boyle, T.P.; Fairchild, J.F. The role of mesocosm studies in ecological risk analysis. Ecol. Appl. 1997, 7, 1099-1102. [CrossRef]

14. Clements, W.H.; Carlisle, D.M.; Courtney, L.A.; Harrahy, E.A. Integrating observational and experimental approaches to demonstrate causation in stream biomonitoring studies. Environ. Toxicol. Chem. 2002, 21, 1138-1146. [CrossRef]

15. Giddings, J.M.; Solomon, K.R.; Maund, S.J. Probabilistic risk assessment of cotton pyrethroids: II. Aquatic mesocosm and field studies. Environ. Toxicol. Chem. 2001, 20, 660-668. [CrossRef] [PubMed]

16. Connolly, N.M.; Pearson, R.G. The effect of fine sedimentation on tropical stream macroinvertebrate assemblages: A comparison using flow-through artificial stream channels and recirculating mesocosms. Hydrobiologia 2007, 592, 423-438. [CrossRef]

17. Quinlan, E.L.; Nietch, C.T.; Blocksom, K.; Lazorchak, J.M.; Batt, A.L.; Griffiths, R.; Klemm, D.J. Temporal Dynamics of Periphyton Exposed to Tetracycline in Stream Mesocosms. Environ. Sci. Technol. 2011, 45, 10684-10690. [CrossRef]

18. Schmitz, J.; Stahlschmidt, P.; Brühl, C.A. Assessing the Risk of Herbicides to Terrestrial Non-target Plants using Higher-tier Studies. Hum. Ecol. Risk Assess. Int. J. 2015, 21, 2137-2154. [CrossRef]

19. Beuter, L.-K.; Dören, L.; Hommen, U.; Kotthoff, M.; Schäfers, C.; Ebke, K.P. Testing effects of pesticides on macroinvertebrate communities in outdoor stream mesocosms using carbaryl as example test item. Environ. Sci. Eur. 2019, 31, 5. [CrossRef]

20. Miller, J.L.; Schmidt, T.S.; Van Metre, P.C.; Mahler, B.J.; Sandstrom, M.W.; Nowell, L.H.; Carlisle, D.M.; Moran, P.W. Common insecticide disrupts aquatic communities: A mesocosm-to-field ecological risk assessment of fipronil and its degradates in U.S. streams. Sci. Adv. 2020, 6, eabc1299. [CrossRef] [PubMed]

21. Reilly, T.J. The Use of Mesocosms in Marine Oil Spill Ecological Research and Development. Pure Appl. Chem. 1999, 71, 153-160. [CrossRef]

22. Silva, D.P.; Duarte, G.; Villela, H.D.; Santos, H.; Rosado, P.M.; Rosado, J.G.; Rosado, A.S.; Ferreira, E.M.; Soriano, A.U.; Peixoto, R.S. Adaptable mesocosm facility to study oil spill impacts on corals. Ecol. Evol. 2019, 9, 5172-5185. [CrossRef] [PubMed]

23. Morales-McDevitt, M.E.; Shi, D.; Knap, A.H.; Quigg, A.; Sweet, S.T.; Sericano, J.L.; Wade, T.L. Mesocosm experiments to better understand hydrocarbon half-lives for oil and oil dispersant mixtures. PLoS ONE 2020, 15, e0228554. [CrossRef] [PubMed]

24. Aljaibachi, R.; Laird, W.B.; Stevens, F.; Callaghan, A. Impacts of polystyrene microplastics on Daphnia magna: A laboratory and a mesocosm study. Sci. Total Environ. 2020, 705, 135800. [CrossRef]

25. Lott, C.; Eich, A.; Unger, B.; Makarow, D.; Battagliarin, G.; Schlegel, K.; Lasut, M.T.; Weber, M. Field and mesocosm methods to test biodegradable plastic film under marine conditions. PLoS ONE 2020, 15, e236579. [CrossRef] [PubMed]

26. McCready, D.; Williams, J.B. A simplified approach to evaluate human and aquatic exposure to a chemical spilled in a river. J. Hazard. Mater. 2011, 193, 225-232. [CrossRef]

27. Chapman, P.M.; Fairbrother, A.; Brown, D. A critical evaluation of safety (uncertainty) factors for ecological risk assessment. Environ. Toxicol. Chem. 1998, 17, 99-108. [CrossRef] 
28. Bejarano, A.C.; Farr, J.K. Development of short, acute exposure hazard estimates: A tool for assessing the effects of chemical spills in aquatic environments. Environ. Toxicol. Chem. 2013, 32, 1918-1927. [CrossRef]

29. OECD. Guidance Document on Simulated Freshwater Lentic Field Tests (Outdoor Microcosms and Mesocosms) OECD Environment Health and Safety Publications Series on Testing and Assessment No. 53; OECD: Paris, France, 2006.

30. Kim, B.S.; Park, Y.G.; Park, G.H.; Jung, M.H.; Yu, A.S.; Yang, Y.J.; Shin, J.S.; Kim, J.H.; Yun, S.M.; Ahn, Y.J. Comparative toxicity of some pesticides on reproduction of Korean native freshwater Cladocerans, Moina macrocopa and Daphnia sp. Korean J. Pestic. Sci. 2007, 11, 246-253.

31. Benider, A.; Tifnouti, A.; Pourriot, R. Growth of Moina macrocopa (Straus 1820) (Crustacea, Cladocera): Influence of trophic conditions, population density and temperature. Hydrobiologia 2002, 468, 1-11. [CrossRef]

32. Nandini, S.; Sarma, S. Reproductive strategies of Moina (Cladocera) in relation to their habitat. Limnetica 2019, 38, 137-145. [CrossRef]

33. Cho, H.; Yoo, J.; Han, Y.; Han, T.; Kim, S.; Jung, J. Toxicity Monitoring of River Sediments in the Geum River Basin using Daphnia magna and Moina macrocopa. J. Korean Soc. Water Environ. 2007, 26, 1000-1007.

34. Yoon, J.-D.; Kim, J.-H.; Park, S.-H.; Jang, M.-H. The Distribution and Diversity of Freshwater Fishes in Korean Peninsula. Korean J. Ecol. Environ. 2018, 51, 71-85. [CrossRef]

35. Kim, J.-H.; Yeom, D.-H.; Kim, W.-K.; An, K.-G. Regional Ecological Health or Risk Assessments of Stream Ecosystems Using Biomarkers and Bioindicators of Target Species (Pale Chub). Water Air Soil Pollut. 2016, 227, 469. [CrossRef]

36. Park, C.-B.; Kim, G.-E.; Kim, D.-W.; Kim, S.; Yeom, D.-H. Biomonitoring the effects of urban-stream waters on the health status of pale chub (Zacco platypus): A comparative analysis of biological indexes and biomarker levels. Ecotoxicol. Environ. Saf. 2021, 208, 111452. [CrossRef] [PubMed]

37. Baek, M.J.; Yoon, T.J.; Bae, Y.J. Development of Glyptotendipes tokunagai (Diptera: Chironomidae) Under Different Temperature Conditions. Environ. Entomol. 2012, 41, 950-958. [CrossRef]

38. NIH. PubChem-Benzyl Chloride [WWW Document]. Natl. Libr. Med. 2004. Available online: https://pubchem.ncbi.nlm.nih.gov/ compound/Benzyl-chloride (accessed on 26 July 2021).

39. NICS (National Institute of Chemical Safety). Technical Guidelines on Accident Scenario Selection; NICS: Deajeon, Korea, 2014.

40. Arar, J.E. EPA Method 446.0 In vitro determination of chlorophylls a, b, c 1c and pheopigments in marine and freshwater algae by visible spectrophotometry, Revision 1.2. In EPA/600/R-97/072; Methods for the Determination of Chemical Substances in Marine and Estuarine; 446.0-1; EPA(Environmental Protection Agency): Washington, DC, USA, 1997; pp. 1-22.

41. Jeffrey, S.W.; Humphrey, G.F. New spectrophotometric equations for determining chlorophylls a, b, c1 and c2 in higher plants, algae and natural phytoplankton. Biochem. Physiol. Pflanz. 1975, 167, 191-194. [CrossRef]

42. Noh, W.; Park, S.; Lee, S.-J.; Ryu, B.-G.; Kim, J. The potential of a natural biopolymeric flocculant, $\varepsilon$-poly-l-lysine, for harvesting Chlorella ellipsoidea and its sustainability perspectives for cost and toxicity. Bioprocess. Biosyst. Eng. 2019, 42, 971-978. [CrossRef] [PubMed]

43. Froese, R. Cube law, condition factor and weight-length relationships: History, meta-analysis and recommendations. J. Appl. Ichthyol. 2006, 22, 241-253. [CrossRef]

44. EPA. National Recommended Water Quality Criteria-Aquatic Life Criteria Table [WWW Document]. 2021. Available online: https:/ / www.epa.gov/wqc/national-recommended-water-quality-criteria-aquatic-life-criteria-table (accessed on 22 July 2021).

45. Bejarano, A.C.; Farr, J.K.; Jenne, P.; Chu, V.; Hielscher, A. The Chemical Aquatic Fate and Effects database (CAFE), a tool that supports assessments of chemical spills in aquatic environments. Environ. Toxicol. Chem. 2016, 35, 1576-1586. [CrossRef]

46. Smit, C.E. Environmental Risk Limits for Benzyl Chloride and Benzylidene Chloride; National Institute for Public Health and the Environment (RIVM) Report 601714016; RIVM: Bilthoven, The Netherlands, 2010.

47. Swann, R.L.; Laskowski, D.A.; McCall, P.J.; Kuy, K.; Dishburger, H.J. A rapid method for the estimation of the environmental parameters octanol/water partition coefficient, soil sorption constant, water to air ratio, and water solubility. Rev. Environ. Contam. Toxicol. 1983, 85, 17-28. [CrossRef]

48. Environment Canada, Health Canada. Screening Assessment for the Challenge Benzene, (Chloromethyl)-(Benzyl Chloride); Chemical Abstracts Service Registry Number 100-44-7; Government of Canada: Vancouver, BC, Canada, 2009.

49. Zou, T.; Zhang, J. A New Fluorescence Quantum Yield Efficiency Retrieval Method to Simulate Chlorophyll Fluorescence under Natural Conditions. Remote Sens. 2020, 12, 4053. [CrossRef]

50. EPA (US Environmental Protection Agency). ECOTOX Knowledgebase [WWW Document]. 2021. Available online: https: //cfpub.epa.gov / ecotox/quick_query.htm (accessed on 19 August 2021). 